\section{Effect of Rolipram on in vitro maturation, gene expression and embryonic development in bovines}

\author{
[Efeito de rolipram na maturação in vitro, expressão gênica e desenvolvimento \\ embrionário em bovinos] \\ B.B. Santana ${ }^{1}$, G.G. Sobral ${ }^{2}$, E.T. Gomes ${ }^{1}$, A.M. Batista ${ }^{3}$, L.P.R. Teixeira ${ }^{4}$, \\ K.C.S. Tavares ${ }^{5}$, M. Bertolini ${ }^{6}$, G.F. Carneiro $^{3}$ \\ ${ }^{2}$ Aluno de graduação - Universidade Federal Rural de Pernambuco - Garanhuns, PE \\ ${ }^{3}$ Universidade Federal Rural de Pernambuco - UFRPE - Recife, PE \\ ${ }^{4}$ Programa de pós-graduação - Universidade de Fortaleza - UNIFOR - Fortaleza, CE \\ ${ }^{5}$ Universidade de Fortaleza - UNIFOR - Fortaleza, CE \\ ${ }^{6}$ Universidade Federal do Rio Grande do Sul - UFRGS - Porto Alegre, RS
}

B.B. Santana1,

http://orcid.org/0000-0001-8121-5270 G.G. Sobral1

http://orcid.org/0000-0001-7906-5023 E.T. Gomes1,

http://orcid.org/0000-0002-6404-0226 A.M. Batista2,

http://orcid.org/0000-0003-1904-0531 L.P.R. Teixeira3,

http://orcid.org/0000-0001-9273-4084

K.C.S. Tavares3,

https://orcid.org/0000-0003-3919-161X

M. Bertolini4,

http://orcid.org/0000-0003-0340-6148

G.F. Carneiro1

${ }^{1}$ Programa de pós-graduação - Universidade Federal Rural de Pernambuco - Garanhuns, PE http://orcid.org/0000-0002-9466-9500

\begin{abstract}
The aim of this work was to evaluate the effect of the Rolipram during the maturation of bovine oocytes and gene expression of embryos produced in vitro. Bovine ovaries were collected in slaughterhouse. The COCs were selected and divided into 5 groups: Control 0 time; Control: IVM for 24 hours; Rolipram treatments with IVM blocking for 24 hours in maturation medium containing $(100,150$ and $200 \mu \mathrm{M})$. After 24 hours all groups were reseated in IVM for another 24 hours. Subsequently COCs were subjected to the same IVM system and fertilized, being checked for cleavage post fertilization and for blastocyst. In addition, performed expression of the following genes: Mater, BMP15 and Bax. No difference was found in gene expression. Of oocytes evaluated shortly after follicular aspiration, $79.00 \%$ were in GV, GVBD, MI, while $13.40 \%$, were in MII and $7.60 \%$, D/NI. Significant difference was observed in different concentrations $(\mathrm{T} 100, \mathrm{~T} 200$ and $\mathrm{T} 150 \mu \mathrm{M})$ in oocytes that have reached the MII phase compared to control treatments $(\mathrm{P}=0.003)$. Differences were observed in cleavage rate $(\mathrm{P}<0.05)$ between $\mathrm{T} 150$ and T200 when compared to the $\mathrm{C} / 24$ Group. A high difference was observed on blastocyst rate $(\mathrm{P}<0.001)$ among treatments compared to the control group.
\end{abstract}

Keywords: bovine, rolipram, IVF, IVM, oocyte

\title{
RESUMO
}

O objetivo deste trabalho foi avaliar o efeito do rolipram durante a maturação de oócitos bovinos, expressão gênica e embriões produzidos in vitro. Os ovários bovinos foram coletados no matadouro. Os COCs foram selecionados e divididos em cinco grupos: controle 0 tempo; controle: MIV por 24 horas; tratamentos rolipram com bloqueio MIV por 24 horas em meio de maturação contendo 100, 150 e

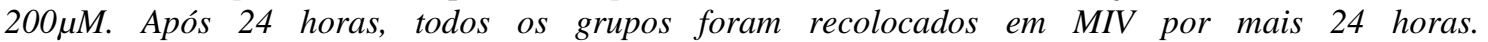
Subsequentemente COCs foram submetidos ao mesmo sistema MIV e fertilizados, sendo avaliada a taxa de clivagem e de blastocisto, além da expressão dos seguintes genes: Mater, BMP15 e Bax. Nenhuma diferença foi observada na expressão gênica. Dos oócitos avaliados logo após a aspiração folicular, 79,0\% estavam em GV, GVBD, MI, enquanto 13,40\% estavam em MII, e 7,60\% em D/NI. A diferença

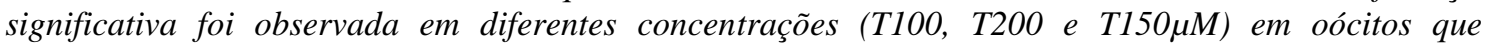
atingiram a fase MII em comparação aos tratamentos de controle $(P=0,3)$. Diferenças foram observadas nas taxas de clivagem $(P<0,5)$ entre T150 e T200 quando comparadas com as taxas do grupo C/24. Uma grande diferença foi observada na taxa de blastocisto $(P<0,1)$ entre os tratamentos em relação ao grupo controle.

Palavras-chave: rolipram, IVF, IVM, oócito, bovino

Recebido em 20 de agosto de 2018

Aceito em 29 de dezembro de 2018

E-mail: brenobarrossantana@hotmail.com 


\section{INTRODUCTION}

Assisted reproductive techniques (ART) are increasingly used in order to solve problems of infertility. The success of these techniques depends on the supply of viable oocytes in a stage suitable for its use (Moura et al., 2009). Despite advances, regarding the improvement of medium and time of exposure to these medium, in vitro production of bovine embryos (IVP) has remained stable, with nuclear maturation and fertilization rates around $80 \%$, and blastocyst production between $35-40 \%$, and on average, only $30 \%$ of these embryos are able to generate pregnancy after transfer (Pontes et al., 2011).

When oocytes are matured in vivo, blastocyst rates improve compared to in vitro matured (IVM). These results demonstrate that IVM is still a limiting step to increase the efficiency of these techniques (Pontes et al., 2009). Oocytes used for IVM are deprived of changes that occur during the period of follicular dominance, because they spontaneously resume meiosis when removed from the follicular environment (Thomas et al., 2002). Therefore, it is likely that many of the oocytes recovered to be used in the ART have a reduced potential for development due to the fact that they are not competent or completely ready to be fertilized (Ponderato et al., 2001). An alternative could be to prevent this premature resumption of meiosis after removing from follicular environment inducing a meiotic block (Adona et al., 2008).

The blockage of meiosis could possibly provide additional time for the oocyte to undergo biochemical and structural changes required to support fertilization and have proper embryonic development (Dieleman et al., 2002). Several substances have been used to block meiosis, such as Adenil Cyclase (AC) activators such as forskolin, maturation-promoting factor (MPF) inhibitors such as 6-dimetilaminopurina (6DMAP), roscovitine and butyrolactone-I and Phosphodiesterase (PDE) inhibitors such as cilostamida, milrinone, rolipram and the 1-3isobutyl, metilxantina (IBMX) (Kubelka et al., 2000; Dode and Adona, 2001; Ponderato et al., 2001; Adona and Leal, 2004).

Among the inhibitors we can highlight the specifics of PDE-4, including Rolipram, whose effect is to prevent the degradation of AMPc in bovine oocytes, resulting in its accumulation in cumulus cells and oocyte, keeping gap junctions stable, retarding resumption of meiosis (Thomas et al., 2002; Gilchrist e Thompson, 2007). These modifications in the conditions of pre-maturing oocyte in a presence of an inhibitor of nuclear maturation has been used in order to achieve a better synchronization between nuclear and cytoplasmic maturation processes (Sirard et al., 1992; Sirard and Coenen, 1993; Franz et al., 2002; Le Beaux et al., 2003; Machatkova et al., 2004).

It is known that oocyte competence is closely related to a certain amount of specific transcripts present in mRNA, accumulated during the development of the oocyte and the final phase of the foliculogenesis (Sirard et al., 2006; Sánchez and Smitz, 2012). In this way, the differences between oocyte viability can also be related to a difference in gene expression patterns of certain transcripts (Caixeta et al., 2009). One of the genes encoding these transcripts include the MATER 1 (maternal antigen that embryos require), BMP15 (bone morphogenetic protein 15), and Bax (protein X) (Hanrahan et al., 2004; Bebbere et al.,2008). Therefore, this work aimed to observe the effect of Rolipram on nuclear stage embryonic development and gene expression of transcribed Mater, BMP15, and BAX.

\section{MATERIALS AND METHODS}

Ethical clearance: Clearance was obtained from the Ethics Committee on Animal Use of the Universidade Federal Rural de Pernambuco CEUA-UFRPE. The study did not involve handling live animals. All reagents used in this study were purchased from Sigma-Aldrich (St. Louis, MO, USA) unless cited. The rolipram (R6520) was diluted in dimethyl sulfoxide (DMSO) to a concentration of $20 \mathrm{mg} / \mathrm{mL}$ and stored at $-20^{\circ} \mathrm{C}$. Bovine oocytes were collected from a local abattoir 5 minutes from the laboratory and immediately transported in saline $0.9 \% \mathrm{NaCl}$, supplemented with $50 \mathrm{mg} / \mathrm{L}$ of gentamicin at a temperature of $37^{\circ} \mathrm{C}$, where 1993 cumulus oocytes complexes (COCs) from follicles between 2 and $8 \mathrm{~mm}$ in diameter were aspirated using $10 \mathrm{~mL}$ syringe attached to $25 \times 8$ needles. 
The COCs were selected from Grade I to Grade III (Blondin and Sirard, 1995). After selection, oocytes were washed in TCM-199 HEPES, which consisted of TCM-199 containing Hank's salts and L-glutamine (Gibco, Life Technologies, NEW YORK, USA) supplemented with $25 \mathrm{mM}$ HEPES, $0.2 \mathrm{mM}$ pyruvate and $0.4 \%$ bovine fetal serum. To evaluate the effect of Rolipram on the resumption of meiosis, COCs $(n=630)$ were divided into eight repetitions with average 16 COCs per group, underwent IVM for 24 hours in the following treatments: T0-stripped, stained and evaluated after aspiration; T1 - IVM medium without inhibitor; $\mathrm{T} 2-100 \mu \mathrm{M}$ rolipram; $\mathrm{T} 3-150 \mu \mathrm{M}$ rolipram and $\mathrm{T} 4-200 \mu \mathrm{M}$ rolipram.

The COCs were transferred to drops of $100 \mu \mathrm{L}$ in a Petri dish (35x10mm Corning, 430165), covered with mineral oil and kept in incubator at $38.5^{\circ} \mathrm{C}$ and $5 \% \mathrm{CO}_{2}$. The IVM medium consisted of TCM-199 containing Earle's salts and Lglutamine (Gibco, Life Technologies, NEW YORK, USA) supplemented with $0.2 \mathrm{mM}$ pyruvate, $2.2 \mathrm{mg} / \mathrm{mL}$ sodium bicarbonate, $5.0 \mathrm{mg} / \mathrm{mL}$ LH (Bioniche, Belleville, ON, Canada), 0.5mg/mL FSH (Bioniche, Belleville, ON, Canada), $0.4 \%$ bovine Fetal Serum and $50 \mu \mathrm{g} / \mathrm{mL}$ gentamicin. After culture, to assess the progression of meiosis, oocytes were denuded and stained with Hoechst $33342(10 \mu \mathrm{g} / \mathrm{mL})$ and analyzed under an epifluorescence microscope (Leica DM2500). Oocytes were classified according to the stage of nuclear maturation as germination vesicle $(\mathrm{GV})$, germinal vesicle break down (GVBD), Metaphase I (MI and Metaphase II (MII).

In order to assess whether the blockage induced meiosis was reversible, COCs from control and treatment groups $(n=431)$ divided into eight repetitions with an average of 13 COCs per group were submitted to IVM for 24 hours under the treatments described. After 24 hours of IVM, COCs were washed with maturation without inhibitor and transferred to drops of $100 \mu \mathrm{L}$ of maturation medium without inhibitor covered by mineral oil and cultured with $38.5^{\circ} \mathrm{C}$ and $5 \%$ $\mathrm{CO}_{2}$ for over 24 hours. After this period, meiotic progression assessment was carried out.

Groups containing 25 COCs, on average, divided into eight repetitions $(n=815)$ after going through the blocking process and resumption of meiosis were fertilized in vitro. For IVF, frozen semen from the same Bull and same batch were used. Frozen semen was thawed at $37^{\circ} \mathrm{C}$ for 30 seconds and prepared according to thePercoll gradient technique (Amersham Biosciences, 170891-01). Sperm were added to micro drops of fertilization at a final concentration of $2 \times 10^{6}$ sperm $/ \mathrm{mL}$. Fertilization was done in TALP-IVF.

The sperm and oocytes were co-incubated in drops of $100 \mu \mathrm{L}$ of medium under mineral oil in a Petri dish (35 x 10mm. Corning, 430165) for a period of 18 hours. After 18 hours of IVF, oocytes were partially stripped with a micropipette of $50 \mu \mathrm{L}$. After partial denudation, oocytes were transferred to SOF (synthetic oviduct fluid) in drops of $100 \mu \mathrm{L}$ and 48 hours of in vitro culture (D3), and the cleavage rate was assesed. Cleaved oocytes remained in the culture medium and the rest were removed and discarded. On the fifth day (D5) of in vitro culture a partial change of medium (feeding $40 \%$ ) was done and from the seventh (D7) and the eighth day (D8) the assessment of blastocyst formation rate (D7) was done. Culture was conducted in an incubator at a temperature of $38.5^{\circ} \mathrm{C}$, containing $5 \% \mathrm{CO}_{2}$ in atmospheric air and $99 \%$ humidity. Every 48 hours, $50 \%$ of the medium was renewed. Cleavage rate was reviewed 48 hours post fertilization (Stringfellow and Seidel, 1998).

Groups composed of 3 to $4 \mathrm{COCs}$, on average, divided into 4 repetitions $(n=117)$ were stripped mechanically after aspiration and in all treatments $24 \mathrm{~h}$ after blockage and $48 \mathrm{~h}$ after blockage release, were stored in $-80^{\circ} \mathrm{C}$ until extraction. Extraction was performed using the buffer lysis of the SuperScript ${ }^{\circledR}$ caps III CellsDirect $^{\mathrm{TM}}$ cDNA Synthesis Kit (Thermo Scientific), adding to each sample $10 \mu \mathrm{L}$ of Resuspension Buffer and $1 \mu \mathrm{L}$ of Lysis Enhancer. Then, the samples were incubated at $75^{\circ} \mathrm{C}$ for $10 \mathrm{~min}$ and treated with DNAse I. Reverse transcription was performed using oligo (dT) 20 starters and the SuperScript III enzyme (Thermo Scientific), according to manufacturer's recommendations, to $50^{\circ} \mathrm{C}$ for 1 hour. The cDNA of each experimental group remained stored in freezer at $-20^{\circ} \mathrm{C}$ until further use.

For the quantification of gene expression in the samples obtained, primers were designed for the genes Mater, BMP15, and Bax. The gene for $\beta$ Actin was used as a reference gene. For each 
primer used, standard curves were performed for determining efficiency of each gene amplification, which were established between 90 and $110 \%$.

For all the qPCRs, the $\operatorname{TaqMan}^{\circledR}$ Gene Expression Master Mix (Thermo Scientific) was used, $1.5 \mu \mathrm{L}$ of cDNA, $400 \mathrm{nM}$ of each primer and $400 \mathrm{nM}$ of TaqMan specific probe (Table 1) in a final volume of $20 \mu \mathrm{L}$. The reactions were incubated at $50^{\circ} \mathrm{C}$ for 2 minutes and $95^{\circ} \mathrm{C}$ for 10 minutes, followed by 50 cycles of $95^{\circ} \mathrm{C}$ for 15 seconds and $60^{\circ} \mathrm{C}$ for 1 minute in a thermal cycler StepOne Plus (Applied Biosystems). Negative controls were prepared with the cDNA omitted during reaction. Reactions were made in duplicate for each sample (from all groups) of their respective repetition in optical 96 wells plates (Applied Biosystems, Foster City, CA, USA). Relative quantification was performed using the $\Delta \Delta \mathrm{CT}$ method (Livak and Schmittgen, 2001), normalizing the results by gene expression of $\beta$-Actin.

All variables studied over the times and treatments have been subjected to ANOVA. The contrasts between the mean were made by Tukey test, with significant difference of $\alpha=0.05$. Sigma Stat 3.1. (SYSTAT Software, Inc., SYSTAT SigmaPlot, SigmaStat are registered trademarks of Systat Software, Inc. 2004) were used.

Table 1. Starters and probes used for determination of gene expression patterns

\begin{tabular}{|c|c|c|c|}
\hline Gene & Primer Forward* & Primer Reverse* & Probe* \\
\hline Mater & GGACCCCAAAGGATGAATTT & GAGCAGAGGTCTTCCCAGTG & GGGCTCCCCAAGGGCTGAAG \\
\hline GDF9 & $\begin{array}{l}\text { TACAACACTGTTCGGCTCTTC } \\
\text { AC }\end{array}$ & $\begin{array}{l}\text { CAACAGTAACACGATCCAGGT } \\
\text { TAAA }\end{array}$ & CCCTGTGCTCAGCACAAGCAGGC \\
\hline BMP15 & $\begin{array}{l}\text { TCGGGTACTACACTATGGTCT } \\
\text { CAATTC }\end{array}$ & $\begin{array}{l}\text { GCCTCAATCAGAAGGATGCTA } \\
\text { ATGG }\end{array}$ & $\begin{array}{l}\text { AGAATGTCCCTCAGCCTTCCTGTG } \\
\text { TCCCT }\end{array}$ \\
\hline BAX & $\begin{array}{l}\text { GTTGTCGCCCTTTTCTACTTT } \\
\text { GC }\end{array}$ & CAACTCGGGCACCTTGGT & ACAGGGCCTTGAGCACC \\
\hline$\beta$ Action. & $\begin{array}{l}\text { CGTGAGAAGATGACCCAGAT } \\
\text { CA }\end{array}$ & GGGACAGCACAGCCTGGAT & $\begin{array}{l}\text { AGACCTTCAACACCCCTGCCATGT } \\
\text { ACGT }\end{array}$ \\
\hline
\end{tabular}

\section{RESULTS}

The oocytes evaluated shortly after follicular aspiration (zero-time control-C/0), $32.00 \%$ $(52 / 159)$ were in germinal Vesicle (GV), $2.60 \%$ $(4 / 159)$ in the germinal vesicle breakdown (GVBD), 44.38\% (70/159) in metaphase I (MI), $13.40 \%(21 / 159)$ in metaphase II (MII), and $7.60 \%(12 / 159)$ degenerates or not identified (D/NI). For the percentage of oocytes that reached M-II, a significant difference was observed between control compared to all treatments $(\mathrm{P}=0,003$; Table 2). In Experiment 1, no difference $(\mathrm{P}>0.05)$ was seen among treatments with oocytes treated at concentrations of 100 (T100), 150 (T150) and $200 \mu \mathrm{M}$ (T200) of Rolipram when compared with the stages of GV, GVGBD, MI. With respect to the percentage of oocytes that have reached the MII phase we observed a reduction as the inhibitor concentration was increasing, showing significant differences $(\mathrm{P}=0.003) \mathrm{T} 100, \mathrm{~T} 150$ and T200, compared to control. With the other treatments, T100 showed no difference (Table 2).

In the second part of the experiment, bovine oocytes treated after 24 hours of blocking have undergone an extra $24 \mathrm{~h}$ of IVM without the blocker and then evaluated according to the stages of nuclear development. No differences $(\mathrm{P}<0.05)$ were observed in any of the stages evaluated (Table 3 ). 
Table 2. Percentage (\%), mean ( $\bar{X}$ ) and Standard Deviation (SD) of nuclear stage from bovine oocytes pre-matured during 24 hours with Rolipram

\begin{tabular}{lllllll}
\hline \multirow{2}{*}{ Groups } & N oocytes $(\bar{X} \pm$ SD $)$ & \multicolumn{7}{l}{ Nuclear Stage $(\%$ and $\bar{X} \pm$ SD $)$} \\
\cline { 3 - 7 } & & GV & GVBD & MI & MII & D/NI \\
\hline \multirow{2}{*}{ C/24 } & 117 & $13(11.12)$ & $0(0.00)$ & $39(33.34)$ & $61(52.13)$ & $4(3.41)$ \\
& $(14.62 \pm 3.20)^{\mathrm{a}}$ & $(1.62 \pm 1.40)^{\mathrm{a}}$ & $(0.00 \pm 0.00)^{\mathrm{a}}$ & $(4.87 \pm 2.47)^{\mathrm{a}}$ & $(7.62 \pm 4.30)^{\mathrm{a}}$ & $(0.50 \pm 0.75)^{\mathrm{a}}$ \\
& 121 & $12(9.92)$ & $9(7.44)$ & $60(49.58)$ & $33(27.28)$ & $7(5.78)$ \\
$\mathrm{T} 100$ & $(15.12 \pm 3.35)^{\mathrm{a}}$ & $(1.50 \pm 0.75)^{\mathrm{a}}$ & $(1.12 \pm 1.88)^{\mathrm{a}}$ & $(7.50 \pm 3.25)^{\mathrm{a}}$ & $(4.12 \pm 2.10)^{\mathrm{b}}$ & $(0.87 \pm 0.99)^{\mathrm{a}}$ \\
& 123 & $21(17.07)$ & $3(2.43)$ & $68(55.29)$ & $18(14.63)$ & $13(10.58)$ \\
T150 & $(15.37 \pm 3.20)^{\mathrm{a}}$ & $(2.62 \pm 1.99)^{\mathrm{a}}$ & $(0.37 \pm 0.51)^{\mathrm{a}}$ & $(8.50 \pm 3.20)^{\mathrm{a}}$ & $(2.25 \pm 2.12)^{\mathrm{b}}$ & $(1.62 \pm 1.76)^{\mathrm{a}}$ \\
& 110 & $22(20.00)$ & $1(0.90)$ & $50(45.46)$ & $26(23.64)$ & $11(10.00)$ \\
T200 & $(13.75 \pm 3.28)^{\mathrm{a}}$ & $(2.75 \pm 1.75)^{\mathrm{a}}$ & $(0.12 \pm 0.35)^{\mathrm{a}}$ & $(6.25 \pm 2.37)^{\mathrm{a}}$ & $(3.25 \pm 1.75)^{\mathrm{b}}$ & $(1.37 \pm 1.76)^{\mathrm{a}}$
\end{tabular}

GV: germinal vesicle; GVBD: germinal vesicle breaks down; MI: metaphase I; MII: metaphase II; D/NI: Degenerated and/or not identified. Different lower case letters in same column indicate statistical difference by ANOVA $(\mathrm{P}<0.05)$ among treatments and distinct phases.

Table 3. Mean $(\bar{X})$ and Standard Deviation (SD) of nuclear stage of bovine oocytes pre-matured during 24 hours with nuclear maturation inhibitor Rolipram, followed by 24 hours of in vitro culture

\begin{tabular}{|c|c|c|c|c|c|c|}
\hline \multirow{2}{*}{ Groups } & \multirow{2}{*}{ N oocytes $/(\bar{X} \pm \mathrm{SD})$} & \multicolumn{5}{|c|}{ Nuclear Stage (\% and $\bar{X} \pm$ SD) } \\
\hline & & GV & GVBD & MI & MII & $\mathrm{D} / \mathrm{NI}$ \\
\hline $\mathrm{C} / 24$ & $\begin{array}{l}117 \\
(14.62 \pm 3.20)^{\mathrm{a}}\end{array}$ & $\begin{array}{l}13(11.12) \\
(1.62 \pm 1.40)^{\mathrm{a}}\end{array}$ & $\begin{array}{l}0(0.00) \\
(0.00 \pm 0.00)^{\mathrm{a}}\end{array}$ & $\begin{array}{l}39(33.34) \\
(4.87 \pm 2.47)^{\mathrm{a}}\end{array}$ & $\begin{array}{l}61(52.13) \\
(7.62 \pm 4.30)^{\mathrm{a}}\end{array}$ & $\begin{array}{l}4(3.41) \\
(0.50 \pm 0.75)^{\mathrm{a}}\end{array}$ \\
\hline T100 & $\begin{array}{l}105 \\
(13.12 \pm 2.85)^{\mathrm{a}}\end{array}$ & $\begin{array}{l}7(6.68) \\
(0.87 \pm 0.83)^{a}\end{array}$ & $\begin{array}{l}1(0.95) \\
(0.12 \pm 0.35)^{\mathrm{a}}\end{array}$ & $\begin{array}{l}25(23.80) \\
(3.12 \pm 2.47)^{\mathrm{a}}\end{array}$ & $\begin{array}{l}61(58.09) \\
(7.62 \pm 2.32)^{\mathrm{a}}\end{array}$ & $\begin{array}{l}11(10.48) \\
(1.37 \pm 1.50)^{\mathrm{a}}\end{array}$ \\
\hline $\mathrm{T} 150$ & $\begin{array}{l}106 \\
(13.25 \pm 1.83)^{\mathrm{a}}\end{array}$ & $\begin{array}{l}9(8.50) \\
(1.12 \pm 1.45)^{\mathrm{a}}\end{array}$ & $\begin{array}{l}1(0.94) \\
(0.12 \pm 0.35)^{\mathrm{a}}\end{array}$ & $\begin{array}{l}24(22.64) \\
(3.00 \pm 0.75)^{\mathrm{a}}\end{array}$ & $\begin{array}{l}62(58.49) \\
(7.75 \pm 2.76)^{\mathrm{a}}\end{array}$ & $\begin{array}{l}10(9.43) \\
(1.25 \pm 1.75)^{\mathrm{a}}\end{array}$ \\
\hline T200 & $\begin{array}{l}111 \\
(13.87 \pm 2.47)^{\mathrm{a}}\end{array}$ & $\begin{array}{l}4(3.60) \\
(0.50 \pm 0.75)^{\mathrm{a}}\end{array}$ & $\begin{array}{l}0(0.00) \\
(0.00 \pm 0.00)^{\mathrm{a}}\end{array}$ & $\begin{array}{l}30(27.03) \\
(3.75 \pm 1.75)^{\mathrm{a}}\end{array}$ & $\begin{array}{l}67(60.37) \\
(8.37 \pm 2.06)^{\mathrm{a}}\end{array}$ & $\begin{array}{l}10(9.00) \\
(1.25 \pm 1.38)^{\mathrm{a}}\end{array}$ \\
\hline
\end{tabular}

GV: germinal vesicle; GVBD: germinal vesicle breaks down; MI: metaphase I; MII: metaphase II; D/NI: Degenerated and/or not identified. Different lower case letters in the same column indicate statistical difference by ANOVA $(\mathrm{P}<0.05)$ among treatments and distinct phases.

In a third experiment, groups of oocytes, after being exposed to the blocker, were fertilized in vitro by IVM process to evaluate cleavage rate in D3 and blastocyst rate in D8, and statistical differences were observed $(\mathrm{P}<0.05)$ on the rate of cleavage between the T150 and T200 when compared to the Group $\mathrm{C} / 24$ and a statistical difference was seen in Blastocyst rate evaluated in $\mathrm{D} 7(\mathrm{P}<0.001)$ all treatments compared to control group (Table 4). 
Table 4. Percentage Mean $(\bar{X})$ and Standard Deviation (SD) from embryonic development of bovine oocytes submitted to a pre-maturation of 24 hours with Rolipram plus 24 hours of in vitro culture without inhibitor

\begin{tabular}{llll}
\hline \multirow{2}{*}{ Groups } & N oocytes $(\bar{X} \pm$ SD $)$ & \multicolumn{2}{l}{ Embryonic Development $(\%-\bar{X} \pm$ SD $)$} \\
\cline { 2 - 3 } Cleaved D3 & Blastocyst D7 \\
\hline \multirow{2}{*}{ T100 } & 203 & $137(67.48)$ & $69(33.99)$ \\
& $(25.37 \pm 9.41)^{\mathrm{a}}$ & $(17.12 \pm 8.00)^{\mathrm{a}}$ & $(6.45 \pm 2.92)^{\mathrm{a}}$ \\
& 200 & $90(45.00)$ & $27(13.25)$ \\
$\mathrm{T} 150$ & $(25.00 \pm 8.99)^{\mathrm{a}}$ & $(11.25 \pm 3.32)^{\mathrm{ab}}$ & $(4.12 \pm 2.64)^{\mathrm{b}}$ \\
& 204 & $81(39.00)$ & $24(11.76)$ \\
$\mathrm{T} 200$ & $(25.50 \pm 7.50)^{\mathrm{a}}$ & $(10.12 \pm 3.27)^{\mathrm{b}}$ & $(4.25 \pm 2.37)^{\mathrm{b}}$ \\
& 208 & $75(36.05)$ & $24(11.53)$ \\
& $(25.00 \pm 5.73)^{\mathrm{a}}$ & $(9.37 \pm 3.06)^{\mathrm{b}}$ & $(4.25 \pm 1.90)^{\mathrm{b}}$ \\
\hline
\end{tabular}

Different lower case letters at the same line indicate statistical difference by ANOVA $(\mathrm{P}<0.05)$ between the same treatment; Different capital letters in the same column indicate statistical difference by ANOVA $(\mathrm{P}<0.05)$ among treatments in distinct phases.

No difference $(\mathrm{P}<0.05)$ was observed with regard to gene expression studies, when compared control groups $0 \mathrm{~h}$ and $24 \mathrm{~h}$ with treatments $24 \mathrm{~h}$ and 48 hours for different transcripts (Figure 1, 2 and 3).

\section{DISCUSSION}

The low blastocyst rates obtained in the in vitro production technique can be justified by the use of immature oocytes, in general these have not yet acquired competence for development, due to their premature withdrawal from the follicular environment. However, it is necessary to develop alternatives to improve IVM techniques, where this will offer appropriate conditions for the majority of oocytes to be capable of producing viable embryos.

One of the first systems used to improve IVM efficiency was based on the proposed Protocol for (Albuz et al., 2010), where some changes were performed in an attempt to simulate the events occurring in in vivo maturation. This system is based on two stages, the first consists of a short period of time using AMPc modulator agents, causing a rapid increase of the intra oocyte levels, similar to the action of $\mathrm{LH}$ in vivo. Oocytes then undergo a period of prolonged IVM, in the presence of a PDE inhibitor, to keep oocytes at GV stage so they have an additional time to suffer modifications that occur before the actual maturation (Hyttel et al., 1997) and to acquire the competence for development (Kubelka et al., 2000; Mermillod et al., 2000).
For this reason, this paper proposed the use of different concentrations of Rolipram, in order to induce meiotic block, reducing the risks of changes in the oocytes and possibly increasing embryonic development rates.

In the first experiment evaluated increasing concentrations of Rolipram (100, 150 and $200 \mu \mathrm{M})$ were evaluated, and their effect on induction of meiotic block. The index of oocyte in $\mathrm{GV}$ found in the control group 0 hour in this study was similar to other studies (Marques $e t$ al., 2011) where they presented an average of 48 . Different data were observed in a study done by other research groups (Dode and Adona, 2001) that reported $100 \%$ of $\mathrm{GV}$ rates at the time 0 hour.

The divergence of data found in the literature can be justified by the relationship between the time of slaughter of the animals and selection of oocytes as well as the use of follicles of 2 to $8 \mathrm{~mm}$. These factors may contribute to the decrease in the resumption of meiosis of oocytes until time of evaluation. On this point, (Fry et al., 1997) and (Machatkova et al., 2000) also noted that bovine oocytes recovered in ovaries of slaughterhouse are heterogeneous in terms of quality and competence, probably due to the diversity of age, breed, and reproductive status (follicle size, day of the estrus cycle, level of atresia and influence of dominant follicles) of cows that pass through the slaughterhouse in a given day which agree with our study because 
slaughtered animals of our region are mostly older animals or withdrawn dairy cows.

In the Group with oocytes blocked with Rolipram it was possible to observe that even increasing Rolipram concentration, there were no differences in effectiveness of meiotic retention. Similar results has been found (Thomas et al., 2004), that did not observe differences using a concentration of $100 \mu \mathrm{M}$ in 9 hours of culture. Lopez et al. (2008) obtained a different result than noted above, when using concentrations of 25,50 and $75 \mu \mathrm{M}$, and noted that the lowest and highest concentration showed lowest rates of maturation being these 31.25 and $28.61 \%$, whereas the concentration of $50 \mu \mathrm{M}$ showed maturation of $76.83 \%$. In our study data were different because the concentrations that obtained lower maturation rate were T150 and T200 where these presented 14.63 and $23.64 \%$ maturation rate. Thomas et al. (2004) using a system of 16 hours of pre-maturation at Rolipram concentrations of 50,250 and $500 \mu \mathrm{M}$ observed a reduction in MII rates with increasing concentration. This factor was not observed in our study.

The response to the block can be caused by several factors such as: the expression of different subtypes of PDE4 (A, B, C and D) or variants generated by alternative splicing, causing a wide variety of Phosphodiesterase isoforms with different catalytic activity regulation mechanisms (Aktas et al., 1995; Bevers et al., 1997). Similar results were described (Marques et al., 2011) where oocytes blocked with Burolactona I $150 \mu \mathrm{M}$ and $50 \mu \mathrm{M}$ Roscovitina showed higher percentage of oocytes in MI compared to GV. Demonstrating possible differences in the maturation kinetics depending on the blocker and its action mechanism. When hormones such as LH and FSH are added in the maturation medium they promote an improvement in COCs expansion (Younis and Brackett, 1992), stimulating production of signaling substances by somatic cells, inducing the resumption of meiosis. This is an important factor to be considered in the low result of oocytes in GV stage in time of prematuration where the medium used in the prematuration was similar to the IVM medium plus the blocker, so this medium has the addition of FSH which may have influenced the oocytes not to remain blocked in $\mathrm{GV}$ and continue maturing until the stage of MI.

Adona et al. (2008) noted that most oocytes treated at concentrations of 100 (B100), 50 (B50) and $25 \mu \mathrm{M}(\mathrm{B} 25)$ of Burolactona I remained blocked on meiosis in the GV stage, on the proportions of $97.4,84.4$ and $65.1 \%$ respectively, with this you can see that the percentage of blockage decreases according to the concentration of the blocker. Similar effect was observed in our study showing 9.92, 17.07 and $20.00 \%$ at concentrations of T100, T200 and $\mathrm{T} 150$ respectively.

Regarding reversibility of meiotic blockage by Rolipram at the end of culture, no difference was seen between control group and treatments, however, differences were seen on GV percentage. Adona et al. (2008), when using the Burolactona I inhibitor in concentrations of 10 and $100 \mu \mathrm{M}$ noted that even with a high rate of oocytes in MII a small portion of oocytes still remained in $\mathrm{GV}$ with 0.0 and 1.1 respectively, as the concentration of the blocker was increasing, the data in this study were varying, but increased when the concentration was T100 and T150 with data from 6.68 to $8.50 \%$ though at the concentration of T200 the amount of oocytes in GV declined to $3.60 \%$

When we compare the oocytes in MII, these showed a variation of 58.09 to $60.37 \%$ depending on Rolipram concentration. Similar data were reported (Marques et al., 2011) with the Roscovitine with $75.31 \%$ of the oocytes and different with Burolactona I with $83.89 \%$ (Kubelka et al., 2000). Thus demonstrating that the pre-matured oocytes with Rolipram regardless of treatment, when compared to other nuclear maturation inhibitors the control group is able to reverse the meiotic block and resume meiosis reaching MII when removed from the medium containing inhibitors. In embryonic development, the present study found differences from cleavage until blastocyst rate. Higher cleavage rate was observed in T150 and T200 being 39.00 and $36.05 \%$. A study (Marques et al., 2011), using Burolactona I and Roscovitine found rates between 20 and $50 \%$ numerically similar to data found in this study (Adona et al., 2008), also using Burolactona did not see differences in the cleavage rate being these 80 $86 \%$. 
Significant difference was observed in blastocyst rate evaluated in D7 between treatments and control group showing rates of $\mathrm{C} / 2433.99 \%$, $13.25 \% \mathrm{~T} 100, \mathrm{~T} 15011.76 \%$ and T200 $11.53 \%$ indicating that when we increase the concentration, the results decreased. Unlike the results of (Adona et al., 2008) and (Marques et al., 2011) in which pre-matured oocytes with Butyrolactone I for 24 hours showed similar results when compared to control group in the production of blastocysts. The likely causes of low efficiency in embryo production could be related to inhibitor concentrations. Lonergan et al. (2000) and Adona et al. (2008) showed that the meiotic block with high concentration of $\mathrm{BL}$ I $(150 \mu \mathrm{M})$ had adverse effects on embryonic development of bovine oocytes.

Rizos et al. (2002) observed that the proportion of embryos produced by IVF is affected by the intrinsic quality of the oocyte, but that the quality of the embryos is affected by in vitro culture. In this sense when nuclear maturation of oocytes occurs over a long period of time, adding the culture and blockage time ( $>42$ hours) can affect the quality of embryos produced. Kim et al. (1997) suggested that oocytes that aged in vitro have decreased embryonic development, mainly by compromising cytoskeletal elements. Two facts should be taken into account in this result: a great time in culture disrupts nuclear and cytoplasmic structures resulting in errors of chromosome pairing and fall in the proportion of fertilization (Long et al., 1995; Hunter and Greve, 1997).

These data suggest that the timing of the in vitro fertilization of oocytes with nuclear maturation inhibitors may affect quality of embryonic development. Lagutina et al. (2002) observed that $82.5 \%$ of the oocytes treated with Roscovitine reached maturation after 16 hours of IVM. The same observations were made (Hashimoto et al., 2002), using Butyrolactone I (more than $85 \%$ of the oocytes in MII with 18 hours of IVM), as well as (Adona and Leal, 2004) who have obtained more than $90 \%$ of the oocytes blocked with Butyrolactone I or Roscovitine in M II after 18 hours of IVM. This fact probably occurs due to the resumption of meiosis in these oocytes to be accelerated after the removal of the inhibitor, and indicates that these oocytes are already able to be fertilized with 16 or 18 hours of IVM.
In the present study we could also analyze the relative abundance of genes potentially involved in oocyte competence, because consequences in meiotic inhibition on expression of some genes have not been discussed at length (Leal et al., 2012). With respect to gene expression, MATER transcripts in mice appear to have an important role in activation of embryonic genome (WU et al., 1996; Tong et al., 2000). MATER transcripts are present in bovine oocytes from primary follicles (Pennetier et al., 2004) and its quantity is reduced with the resumption of meiosis, in both in vitro and in vivo maturation (Thélie et $a l .$, 2007). Which agree with the numerical drop in number of transcripts observed in our study when we compare the $0 \mathrm{~h}$ group with treatment groups.

However, variations in the amount of these transcripts may not be associated with oocyte competence to develop after in vitro fertilization (Mota et al., 2009). In a study conducted by (Wu et al., 1996;) and (Tong et al., 2000) with mice, it was possible to observe that although in the absence MATER adequate follicular development occurs, ovulation and fertilization with normal zygotes, embryos obtained do not develop beyond the 2-cell stage and tend to degenerate. Therefore, the block on the development observed in embryos cultured in vitro, which coincides with the EGA, are possibly related with the least amount of MATER reported in bovine oocytes matured in vitro (Pereira et al., 2010). This result is similar to our study, where concentrations of T150 T200 showed the smallest quantities of transcripts and subsequently lower rates of cleavage and blastocyst formation. With respect to the profile of expression (Bebbere et al., 2008), in his studies with sheep, there was a decreased level of MATER along with oocyte maturation. Similar results have been found in mice (Wu et al., 1996) and pigs (Uzbekova et al., 2006).

Aa study in sheep found that mRNA BMP15 remained constant until the embryo reached the 8 cell stage after which there was a significant reduction, apparently being more important in later stages of development (Bebbere et al., 2008). It was possible to notice that as you increased concentration of Rolipram there was an increase in BMP15 gene expression demonstrating that this substance has influence on the expansion of cumulus cells, which reflects 
directly on oocyte maturation. The lowest value of BMP15 has been the concentration of T100, which also presented highest rates of cleavage and blastocyst formation between treatments.

The correlation of Bax overexpression with the acceleration of apoptosis is known, where evidence shows that oocytes with low Bax gene expression have a higher ability to stay viable with smaller probability of degeneration (Felici et al., 1999). Yang and Rajamahendran (2002) observed that the expression of BAX protein was higher in degenerated embryos and concluded that apoptosis is responsible for oocyte degeneration, fragmentation of the embryo and embryo loss. In our study we found that values of BAX among $24 \mathrm{~h}$ treatment have increased according to the elevation of the blocker concentration, and correlate with the greater the concentration a higher meiotic block, suggesting that the oocytes are not yet competent or in acceleration of apoptosis and so less able to remain viable. On the other hand, after unblocking, there is a drop in the values of this gene expression showing no difference between treatments and values a bit higher than the C24, but still low cleavage rate and blastocyst formation suggesting that the block with Rolipram may predispose the acceleration of apoptosis, decreasing their ability to remain viable.

Data on the influence of IVM on BAX gene expression in bovine embryos are still scarce. Warzych et al., (2007) published data on the expression of this gene in embryos resulting from oocytes matured in different culture conditions. However, we did not observe changes in relative abundance of transcripts of BAX in bovine oocytes and hatched blastocysts after in vitro maturation in medium supplemented with PVP-40, BSA or BFS (bovine fetal serum).

\section{CONCLUSION}

It can be concluded that the use of Rolipram in a maturation system in concentrations of 100, 150 and $200 \mu \mathrm{M}$ can provide a delay in nuclear maturation in MI without changing its reversibility irrespective of the concentration used and the concentration of $100 \mu \mathrm{M}$ can be used in a way that will not interfere significantly with embryonic development.

\section{ACKNOWLEDGMENTS}

The authors are grateful to FACEPE for the scholarship. To Garanhuns Bovine Clinic and Dr. José Augusto Bastos Afonso.

\section{REFERENCES}

ADONA, P.R.; LEAL, C.L.V. Meiotic inhibition with different cyclin dependent kinase inhibitors in bovine oocytes and its effects on maturation and embryo development. Zygote, v.12,p.97-204, 2004.

ADONA, P.R.; PIRES, P.R.; QUETGLAS, M.D.; SCHWARZ, K.R. et al. Prematuration of bovine oocytes with butyrolactone I: effects on meiosis progression, cytoskeleton, organelle distribution and embryo development. Anim. Reprod. Sci., v.108, p.49-65, 2008.

AKTAS, H.; WHEELER, M.B.; FIRST, N.L.; LEIBFRIED-RUTLEDGE, M.L. Maintenance of meiotic arrest by increasing [cAMP]i may have physiological relevance in bovine oocytes. $J$. Reprod. Fertil., v.105, p.237-245, 1995.

ALBUZ, F.K.; SASSEVILLE, M.; LANE, M. et al Simulated physiological oocyte maturation (SPOM): a novel in vitro maturation system that substantially improves embryo yield and pregnancy outcomes. Hum. Reprod., v.25, p.2999-3011, 2010

BEBBERE, D.; BOGLIOLO, L.; ARIU, F. et al. Expression pattern of zygote arrest 1 (ZARl), maternal antigen that embryo requires (MATER), growth differentiation factor $9(G D F 9)$ and bone morphogenetic protein 15 (BMP15) genes in ovine oocytes and in vitro-produced preimplantation embryos. Reprod. Fertil. Dev., v.20, p.908-915, 2008.

BEVERS, M.M.; DIELEMAN, S.J.; VAN DEN HURK, R.; IZADYAR, F. Regulation and modulation of oocyte maturation in the bovine. Theriogenology, v.47, p.13-22, 1997.

BLONDIN, P.; SIRARD, M.A. Oocyte and follicular morphology as determining characteristics for developmental competence in bovine oocytes. Mol. Reprod. Dev., v.41, p.5462, 1995.

CAIXETA, E.S.; RIPAMONTE, P.; FRANCO, M.M. et al. Effect of follicle size on mRNA expression in cumulus cells and oocytes of Bos 
indicus: an approach to identify marker genes for developmental competence. Reprod. Fertil. Dev., v.21, p.655-664, 2009.

DIELEMAN, S.J.; HENDRIKSEN, P.J.M.; VIUFF, D. et al. Effects of in vivo prematuration and in vivo final maturation on developmental capacity and quality of pre-implantation embryos. Theriogenology, v.57, p.5-20, 2002.

DODE, M.; ADONA, P.R. Developmental capacity of Bos indicus oocytes after inhibition of meiotic resumption by 6dimetylalaminopurine. Anim. Reprod. Sci., v.65, p.171-180, 2001.

FELICI, M.D.; CARLO, A.D.; PESCE, M. et al. $\mathrm{Bcl}-2$ and Bax regulation of apoptosis in germ cells during prenatal oogenesis in the mouse embryo. Cell Death Differ., v.6, p.908-915, 1999.

FRANZ, L.C.; SQUIRES, E.L.; RUMPF, R. et al. Effects of roscovitine in maintaining meiotic arrest in equine oocytes and subsequent maturation rates after inhibition. Theriogenology, v.58, p.679-683, 2002.

FRY, R.C.; NIALL, E.M.; SIMPSON, T.L. et al. The collection of oocytes from bovine ovaries. Theriogenology, v.47, p.977-987, 1997.

GILCHIST, R.B.; THOMPSON, J.G. Oocyte maturation: emerging concepts and technologies to improve developmental potential in vitro. Theriogenology, v.67, p.6-15, 2007.

HANRAHAN, J.P.; GREGAN, S.M.; MULSANT, P. et al. Mutations in the genes for oocyte-derived growth factors GDF9 and BMP15 are associated with both increased ovulation rate and sterility in Cambridge and Belclare sheep (Ovis aries). Biol. Reprod., v.70, p.900-909, 2004.

HASHIMOTO, S.; MINAMI, N.; TAKAKURA, R.; IMAI, H. Bovine immatureoocytes acquire developmental competence during meiotic arrest in vitro. Biol. Reprod., v.66, p.1696-1701, 2002.

HUNTER, R.H.F.; GREVE, T. Could artificial insemination of cattle be more fruitful? Penalties associated whith aging eggs. Reprod. Domest. Anim., v.32, p.137-141, 1997.
HYTTEL, P.; FAIR, T.; CALLESEN, H.; GREVE, T. Oocyte growth capacitation and final maturation in cattle. Theriogenology, v.47, p.2332.1997.

KIM, K.S.; MINAMI, N.M.; UTSUMI, K. Follicular cells affect the fertilizability and developmental competence of bovine oocyte in vitro. Reprod. Fertil. Dev., v.9, p.763-766, 1997.

KUBELKA, M.; MOTLIK, J.; SCHULTZ, R.M.; PAVLOK, A. Butyrolactone I reversibly inhibits meiotic maturation of bovine oocytes, without influencing chromosome condensation activity. Biol. Reprod., v.62, p.292-302, 2000.

LAGUTINA, I.; PONDERATO, N.; LAZZARI, G.; GALLI, C. Kinetics of oocyte maturation and subsequent development of IVF, parthenogenetic, and NT bovine embryos after meiotic inhibition with roscovitinre. Cloning Stem Cells, v.4, p.113-119, 2002.

LE BEAUX, G.; RICHARD, F.J.; SIRARD, M.A. Effect of cycloheximide, 6-DMAP, roscovitine and butyrilactone I on resumption of meiosis in porcine oocytes. Theriogenology, v.60, p.1049-1058, 2003.

LEAL, C.L.V.; MAMO, S.; FAIR, T.; LONERGAN, P. Gene expression in bovine oocytes and cumulus cells after meiotic inhibition with the cyclin-dependent kinase inhibitor butyrolactone I. Reprod. Domest. Anim., v.47, p.615-624, 2012.

LIVAK, K.J; SCHMITTGEN, T.D. Analysis of relative gene expression data using realtime quantitative PCR and the $2 \Delta \Delta \mathrm{C}(\mathrm{T})$ Method. Methods v.25(4), p.402-408, 2001.

LONERGAN, P.; GUTIÉRREZ-ADÁN, A.; PINTADO, B. et al.Relationship between time of first cleavage and the expression of IGF-1 growth factor, its receptor, and two housekeeping genes in bovine two-cell embryos and blastocysts produced in vitro. Mol. Reprod. Dev., v.57, p.146-152, 2000.

LONG, C.R.; HYTTEL, P.; FAIR, T. et al. Oocyte growth, capacitation and final maturation in catlle. Theriogenoly, v.43, p.51-80, 1995.

LÓPEZ, Y.S.; MEJÍA, A.M.; ESCOBAR, E.E. et al. Efecto del inhibidor de fosfodiesterasa tipo 4 -rolipram, sobre la maduración in vitro de oocitos bovinos. Rev. Colomb. Ciênc. Pecu., v.21, p.59-65, 2008. 
MACHATKOVÁ, M.; JOKESOVÁ, E.; HORKY, F. Utilization of the growth phase of the first follicular wave for bovine oocyte collection improves blastocyst production. Theriogenology, v.54, p.543-550, 2000.

MACHATKOVA, M.; KRAUSOVA, K.; JOSEKOV, E.; TOMANEK, M. Developmental of bovine oocytes: effects of follicle size and the phase of follicular wave on in vitro embrio production. Theriogenology, v.61, p.329-335, 2004.

MARQUES, M.G.; MELLO, M.R.B.D.; TAVARES, L.M.T. et al. Maturação e desenvolvimento embrionário in vitro de oócitos bovinos após bloqueio da meiose com inibidores de MPF. Braz. J. Vet. Res. Anim. Sci., v.48, p.468-477, 2011.

MERMILLOD, P.; TOMANEK, ; MARCHAL, ; MEIJER, L. High developmental competence of cattle oocytes maintained at the germinal vesicle stage for 24 hours in culture by specificinhibition of MPF kinase activity. Mol. Reprod., v.55, p.8995, 2000.

MOTA, G.B.; BATISTA, R.I.T.P.; SERAPIAO, R.V. et al. Developmental competence and expression of the MATER and ZAR1 gene in immature bovine oocytes selected by Brilliant Cresyl Blue. Zygote, v.26, p.1-8, 2009.

MOURA, M.D.D.; SOUZA, M.D.; CARMO, B.D.; SCHEFFER, B.B. Reprodução assistida. Um pouco de história. Rev. Soc. Bras. Psicol. Hosp., v.12, p.2-10, 2009.

PENNETIER, S.; UZBEKOVA, S.; PERREAU, C. et al. Spatio-temporal expression of the germ cell marker genes MATER, ZAR1, GDF9, BMP15, and VASA in adult bovine tissues, oocytes, and preimplantation embryos. Biol. Reprod., v.71, 1359-1366, 2004.

PEREIRA, M.M.; COSTA, F.Q.; OLIVEIRA, A.P. et al. Quantificação de transcritos maternos em oócitos bovinos submetidos a diferentes condições de maturação. Arq. Bras. Med. Vet. Zootec., v.62, p.1394-1400, 2010.

PONDERATO, N.; LAGUTINA, I.; CROTTI, G.; TURINI, P. et al. Bovine oocytes treated prior to in vitro maturation with a combination of butyrolactone I and roscovitine at low doses maintain a normaL development capacity. Mol. Reprod. Dev., v.60, p.579-585, 2001.
PONTES, J.H.F.; MELO-STERZA, F.A.; BASSO, A.C. et al. Ovum pick up, in vitro embryo production, and pregnancy rates from a large-scale commercial program using Nelore cattle (Bos indicus) donors. Theriogenology, v.75, p.1640-1646, 2011.

PONTES, J.H.F.; NONATO-JUNIOR, I.; SANCHEZ, B.V.; ERENO-JUNIOR, J.C. et al. Comparison of embryo yield and pregnancy rate between in vivo and in vitro methods in the same Nelore (Bos indicus) donor cows. Theriogenology, v.71, p.690-697, 2009.

RIZOS, D.; FAIR, T.; PAPADOPOULOS, S. et al. Developmental, qualitative, and ultrastructural differences between ovine and bovine embryos produced in vivo or in vitro. Mol. Reprod. Dev., v.62, p.320-327, 2002.

SÁNCHEZ, F.; SMITZ, J. Molecular control of oogenesis. Biochim. Biophys. Acta, v.12, p.18961912, 2012.

SIRARD, M.A.; COENEN, K.; BILODEAU, S. Effect of fresh or cultured follicular fractions on meiotic resumption in bovine oocytes. Theriogenology, v.37, p.39-55, 1992.

SIRARD, M.A.; RICHARD, F.; BLONDIN, P.; ROBERT, C. Contribution of the oocyte to embryo quality. Theriogenology, v.65, p.126362, 2006.

SIRARD, M.A.; COENEN, K. The co-culture of cumulus-enclosed bovine oocytes and hemissections of follicles: effects on meiotic resumption. Theriogenology, v.40, p.933-942, 1993.

STRINGFELLOW, D.A.; SEIDEL, S.M. (Eds.). Manual da sociedade internacional de transferência de embriões: um guia de procedimento e informações gerais para uso em tecnologia de transferência de embriões enfatizando procedimentos sanitários. Illinois: Savoy, 1998. p.180.

THÉLIE, A.; PAPILlIER, P.; PENNETIER, S. et al. Differential regulation of abundance and deadenylation of maternal transcripts during bovine oocyte maturation in vitro and in vivo. Biol. Reprod., v.7, p.1-13, 2007. 
THOMAS, R.E.; THOMPSON, J.; ARMSTRONG, C.G.; GILCHRIST, R.B. Effect of specific phosphodiesterase isoenzyme inhibitors during in vitro maturation of bovine oocytes on meiotic and developmental capacity. Biol. Reprod., v.71, p.1142-1149, 2002.

THOMAS, R.E.; THOMPSON, J.; ARMSTRONG, C.G; GILCHRIST, R.B. Bovine cumulus-cell-oocyte gap junctional communication during in vitro maturation in response of cell-specific cyclic adenosine 3', 5'monophosphate cyclic levels. Biol. Reprod., v.70, p.548-556, 2004.

TONG, Z.B.; GOLD, L.; PFEIFER, K.E. et al. Mater, a maternal effect gene required for early embryonic development in mice. Nat. Genet., v.26, p.267-278, 2000.

UZBEKOVA, S.; ROY-SABA, M.; DALBIÈSTRAN, R. et al. Zygote arrest 1 gene in pig, cattle and human: evidence of different transcript variants in male and female germ cells. Reprod. Biol. Endocrinol., v.4, p.4-12, 2006.
WARZYCH, E.; PEIPPO, J.; SZYDLOWSKI, M.; LECHNIAK, D. Supplements to in vitro maturation media affect the production of bovine blastocysts and their apoptotic index but not the proportions of matured and apoptotic oocytes. Anim. Reprod. Sci., v.97, p.334-343, 2007.

WU, B.; IGNOTZ, G.G.; CURRIE, W.B.; YANG, X. Temporal distinctions in the synthesis and accumulation of proteins by oocytes and cumulus cells during maturation in vitro of bovine oocytes. Mol. Reprod. Dev., v.45, p.560$565,1996$.

YANG, M.Y.; RAJAMAHENDRAN, R. Expression of Bcl-2 and Bax proteins in relation to quality of bovine oocytes and embryos produced in vitro. Anim. Reprod. Sci., v.70, p.159-169, 2002.

YOUNIS, A.I.; BRACKETT, B.G. Thyroid stimulating hormone enhancement of bovine oocyte maturation in vitro. Mol. Reprod. Dev., v.31, p.144-151, 1992. 